\title{
Cold- and Warm-temperature Acclimation Induces Specific Cytosolic Proteins in Goldfish and Carp
}

\author{
Shugo Watabe, ${ }^{* 1}$ Kiyoshi Kikuchi, ${ }^{* 2}$ and Katsumi Aida*2 \\ (Received August 19, 1992)
}

\begin{abstract}
Goldfish Carassius auratus, and carp Cyprinus carpio for comparison, were acclimated to either 10 or $30^{\circ} \mathrm{C}$, and their cytosolic protein compositions in several tissues were analyzed electrophoretically. Two-dimensional electrophoresis employing isoelectric focusing and SDS-PAGE revealed the increased abundance of a $65 \mathrm{kDa}$ protein in muscle in $30^{\circ} \mathrm{C}$-acclimated fish, while a $55 \mathrm{kDa}$ protein was predominant in the $10^{\circ} \mathrm{C}$-acclimated counterparts. Goldfish brain and liver tissues exhibited similar changes in an acclimation temperature-dependent manner. These results suggest that the cytosolic 55 and $65 \mathrm{kDa}$ proteins are distributed to various tissues of coldand warm-acclimated fish, respectively.
\end{abstract}

When a poikilotherm is transferred from one thermal regime to another, many aspects of its physiology and biochemistry are altered in a manner that compensates for the temperature change. ${ }^{1)}$ Such compensations can be established after a relatively short period, usually a few weeks in duration, in the case of eurythermal temperate fish such as goldfish and carp.

This is manifest in part by changes in enzymatic activities. These enzymatic alterations may be attributable to either quantitative alterations of enzyme synthesis, qualitative changes in isozyme expressions, or changes in lipid composition of membrane bilayers. Compensations are also evident at a more complex level via changes in the relative activities of alternative metabolic pathways. ${ }^{1}$ Since acclimatory responses require a few weeks to occur, it seems that they involve genetic regulations in protein synthetic systems. For example, myofibrillar ATPase activity is increased in carp and goldfish after cold acclimation. 2.33 These changes in ATPase activity are associated with different isoform expressions of myosin, a major protein constituent of the myofibril.4, 5 . Myosin isoforms have different primary structures, ${ }^{B}$ which are translated by different mRNAs. ${ }^{7}$ ' However, it is not clear how these isoform expressions are regulated in eurythermal temperate fish at the protein synthetic level. Since myosin has a very large molecular weight of about 500,000 and multiple isoforms, it seems not practical to employ this protein as a candidate for studying the genetic regulation of protein synthesis during temperature acclimation of fish.

This study was undertaken to investigate changes in cytosolic protein composition of goldfish and carp by temperature acclimation; one objective was to examine the presence of candidate proteins which can substitute for myosin and be useful for future research on the molecular biology of temperature acclimation in fish. A preliminary report on this investigation has been presented elsewhere. ${ }^{g)}$

\section{Materials and Methods}

\section{Materials}

Goldfish Carassius auratus (36-45 g) and carp Cyprinus carpio $(0.6-0.9 \mathrm{~kg})$ were acclimated to either 10 or $30^{\circ} \mathrm{C}$ for a minimum of five weeks in laboratory aquariums. All fish were fed commercial pellets daily ad libitum. After acclimation, fish were sacrificed and the white epaxial muscle, liver, and brain were removed. In order to compare cytosolic protein patterns between cold- and warm-acclimated goldfish, the muscle, liver, and brain from 16,10, and 10 individuals for each of the two acclimation groups respectively were subjected to electrophoretic analyses. In the case of carp, 9 individuals from each of the two acclimation

*1 Laboratory of Marine Biochemistry, Faculty of Agriculture, The University of Tokyo, Yayoi, Bunkyo,

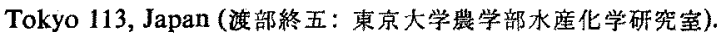

*2 Laboratory of Fish Physiology, Faculty of Agriculture, The University of Tokyo, Yayoi, Bunkyo, Tokyo 113, Japan (菊池，㵖，会田勝美：東京大学㖘学部魚類生理学研究室). 
groups were analyzed.

\section{Preparation of Cytosolic Proteins}

Muscle and liver were homogenized in an equal volume of an ice-cold $1: 1(\mathrm{v} / \mathrm{v})$ mixture of $0.06 \mathrm{M}$ barbital buffer (pH 8.6) and glycerol. The two homogenates were centrifuged at $33,000 \times$ $\mathrm{g}$ for $15 \mathrm{~min}$ and the resulting supernatants were used for electrophoretic analyses. In the case of the brain, 4 volumes of the same buffer were added to homogenize tissues.

\section{Electrophoretic Analyses}

SDS-PAGE was performed by the method of Laemmli ${ }^{\mathrm{C})}$ using $7.5-20 \%$ polyacrylamide gradient slab gels containing $0.1 \%$ SDS. Two-dimensional electrophoresis was performed by the method of O'Farrel1 ${ }^{10)}$ using $4 \%$ polyacrylamide gels in the presence of $8 \mathrm{M}$ urea and $1 \%$ Ampholine (comprising $0.8 \% \mathrm{pH}$ range $5-8$ and $0.2 \% \mathrm{pH}$ range $3.5-10$ ) for isoelectric focusing and $12 \%$ slab gels for SDS-PAGE. Gels were stained with $0.1 \%$ Coomassie brilliant blue R250 after conventional one-dimensional SDS-PAGE, or with silver nitrate after two-dimensional electrophoresis according to Oakley et al. ${ }^{11}$ Sample volumes applied were 20 and $8 \mu l$ for one-dimensional SDS-PAGE and two-dimensional electrophoresis, respectively. Standard molecular weight markers (Sigma) were myosin heavy chain from rabbit muscle $(205,000=205 \mathrm{kDa}), \beta$-galactosidase from $E$. coli $(116 \mathrm{kDa})$, phosphorylase $b$ from rabbit muscle $(97 \mathrm{kDa})$, bovine serum albumin (66 kDa), ovalbumin (45 kDa), and carbonic anhydrase from bovine erythrocytes (29 kDa).

\section{Results}

Cytosolic Proteins from Goldfish and Carp Muscles

Two cytosolic proteins were found to be predominant in both goldfish and carp muscles by one-dimensional SDS.PAGE followed by $\mathrm{Co}-$ omassie brilliant blue staining (data not shown). They had molecular masses of approximately 45 and $12 \mathrm{kDa}$ and were regarded as creatine kinase and parvalbumin, respectively, according to Nakagawa et al. ${ }^{12}$ and Hamoir. ${ }^{13}$ However, differences were hardly observed in electrophoretic patterns between the $10^{\circ} \mathrm{C}$ - and $30^{\circ} \mathrm{C}$-acclimated fish.

When cytosolic proteins from the muscle were subjected to two-dimensional electrophoresis and subsequently stained by a more sensitive method with silver nitrate, both goldfish and carp exhibited variations according to their acclimation temperatures in the relative abundances of the 65 and $55 \mathrm{kDa}$ protein components. Figure $1 \mathrm{~A}$ shows typical patterns from 16 individuals each for the two types of acclimated goldfish. Besides the large quantities of creatine kinase located in the center of the gels, the $30^{\circ} \mathrm{C}$-acclimated golfish showed an increased abundance of the $65 \mathrm{kDa}$ protein, whereas the $10^{\circ} \mathrm{C}$-acclimated ones showed increases in the $55 \mathrm{kDa}$ protein. It was noted that these two proteins were both extremely acidic. Similar changes were observed with cytosolic muscle proteins from the $10^{\circ} \mathrm{C}$ and $30^{\circ} \mathrm{C}$-acclimated carp, although the two groups of carp contained more quantities of proteins with molecular weights less than that of creatine kinase, compared to goldfish (Fig. 1B). Thus far, no sex-dependent variations have been observed in goldfish or carp.

\section{Cytosolic Proteins from Goldfish Liver}

The same analytical methods as those adopted for muscle were used for cytosolic proteins from goldfish liver (Fig. 2). One-dimensional SDSPAGE showed that 97 and $28 \mathrm{kDa}$ proteins increased remarkably in the liver following $30^{\circ} \mathrm{C}$ acclimation (Fig. 2A). Other proteins were roughly constant irrespective of acclimation temperatures, except for some proteins with molecular weights of approximately $45 \mathrm{kDa}$ which were abundant, though with individual variation, in the $10^{\circ} \mathrm{C}$-acclimated liver. It was noted that a $120 \mathrm{kDa}$ component expressed in the $10^{\circ} \mathrm{C}$-acclimated goldfish liver was found only in female fish.

Two-dimensional electrophoretic patterns of liver cytosolic proteins were less clear than those of muscle proteins, probably due to contaminating lipids (Fig. 2B). However, it was demonstrated that the $65 \mathrm{kDa}$ protein was again increased in the liver by the $30^{\circ} \mathrm{C}$-acclimation as in the case of muscle tissues. The increased abundance of the $28 \mathrm{kDa}$ protein in the $30^{\circ} \mathrm{C}$-acclimated goldfish was also observed in the two-dimensional electrophoretic gel.

\section{Cytosolic Proteins from Goldfish Brain}

The cytosolic protein composition of goldfish brain was analyzed only by two-dimensional electrophoresis, since protein concentrations were not sufficient to develop electrophoretic patterns 


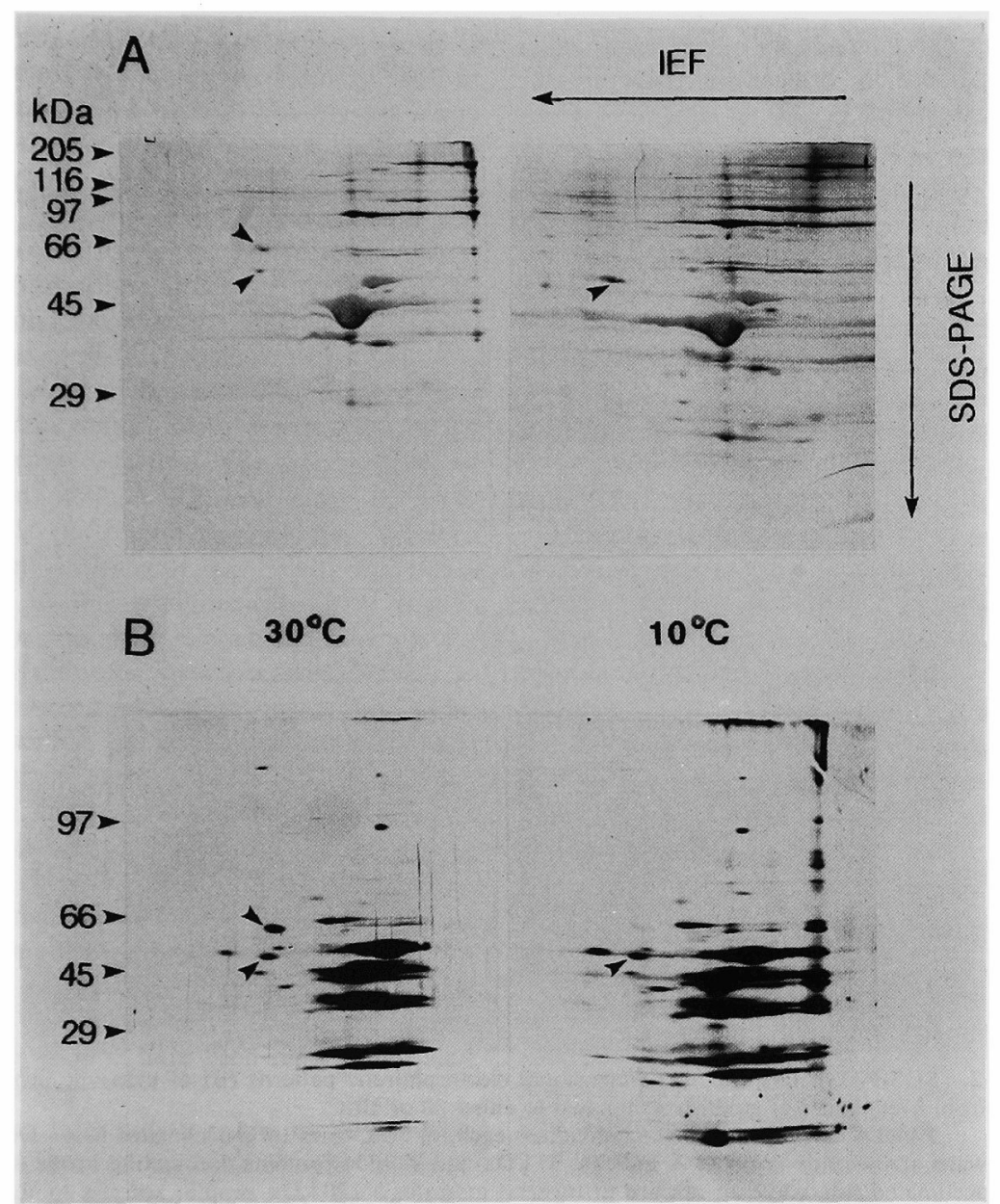

Fig. 1. Two-dimensional electrophoretic patterns of cytosolic proteins from muscle tissues of goldfish (A) and carp (B) acclimated to either 30 or $10^{\circ} \mathrm{C}$.

Downward arrowheads indicate the $65 \mathrm{kDa}$ protein dominating in the $30^{\circ} \mathrm{C}$-acclimated fish, whereas upward arrowheads indicate the $55 \mathrm{kDa}$ protein dominating in the $10^{\circ} \mathrm{C}$-acclimated fish. Numbers in the extreme left of panel A indicate molecular masses of standard proteins.

by Coomassie blue staining. When gels were stained with silver nitrate, protein profiles were similar to those of the muscle and liver extracts in an acclimation temperature-dependent manner with respect to the 55 and $65 \mathrm{kDa}$ components (Fig. 3). These results suggest that the two acidic components having molecular mass of 65 and $55 \mathrm{kDa}$ are ubiquitous proteins which would be expressed in response to temperature acclimation in various tissues of goldfish and carp.

\section{Discussion}

The two-dimensional electrophoretic analyses of cytosolic proteins from muscle, liver, and brain of goldfish or carp revealed that the 55 and $65 \mathrm{kDa}$ protein components increased their quantities during cold- and warm-temperature acclimation, respectively. These results led to the speculation that one of adaptive strategies in temperate freshwater fish in response to environmental temperature changes is via quantitative alterations of temperature acclimation- 


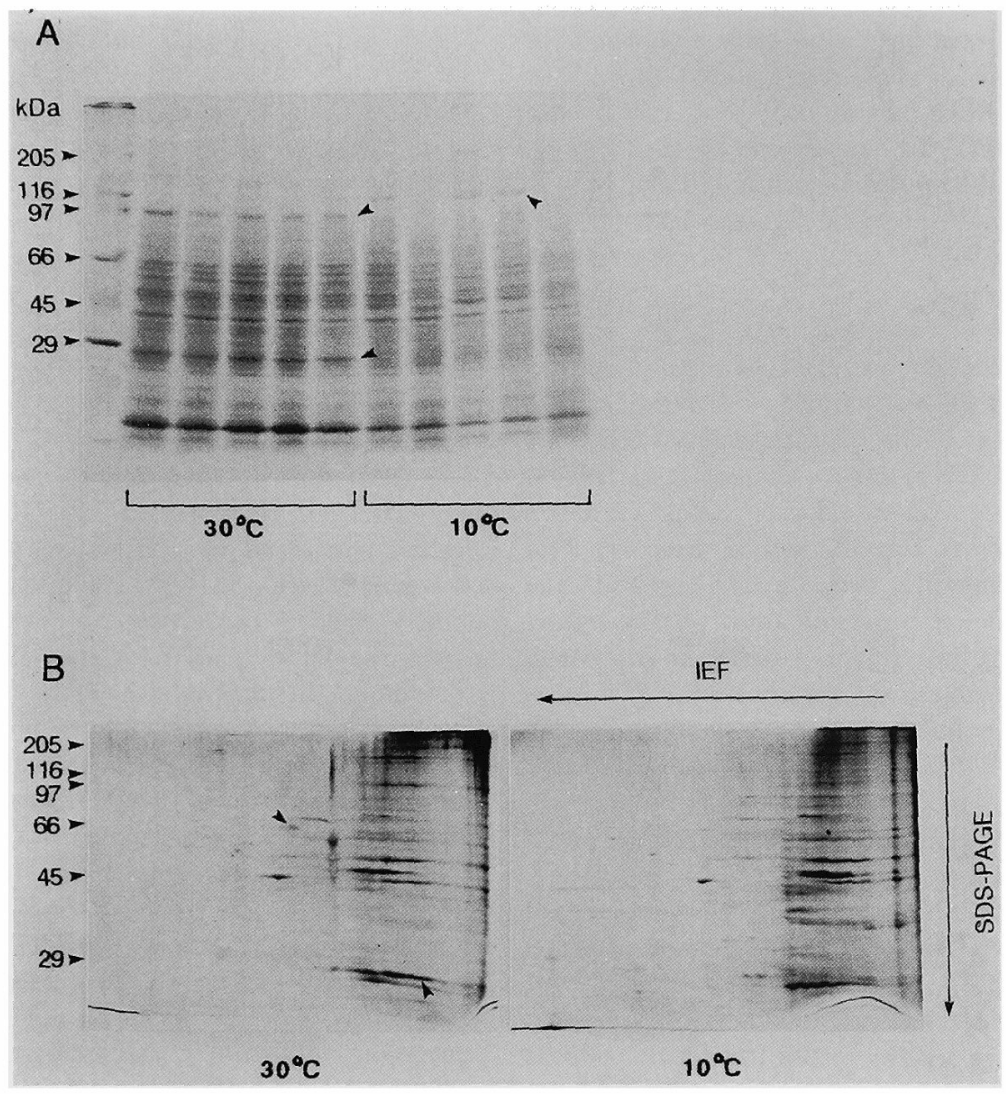

Fig. 2. SDS-PAGE (A) and two-dimensional electrophoretic patterns (B) of cytosolic proteins from liver tissues of goldfish acclimated to either 30 or $10^{\circ} \mathrm{C}$.

Panel A shows patterns of 5 individuals each for $30^{\circ} \mathrm{C}$ - and $10^{\circ} \mathrm{C}$-acclimated fish. Downward arrowheads in panel $\mathrm{A}$ indicate $97 \mathrm{kDa}$ and $28 \mathrm{kDa}$ proteins dominating in the $30^{\circ} \mathrm{C}$ acclimated fish, while an upward arrowhead indicates a $120 \mathrm{kDa}$ protein specific to female fish. Downward and upward arrowheads in panel $\mathrm{B}$ indicate the $65 \mathrm{kDa}$ and $28 \mathrm{kDa}$ proteins, respectively, dominating in the $30^{\circ} \mathrm{C}$-acclimated fish.

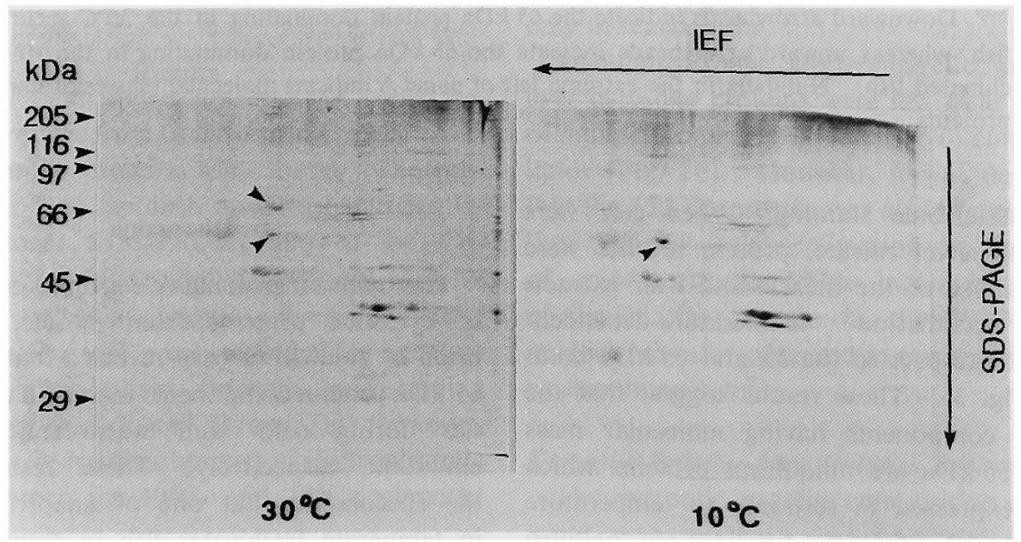

Fig. 3. Two-dimensional electrophoretic patterns of cytosolic protein from brain tissues of goldfish acclimated to either 30 and $10^{\circ} \mathrm{C}$ for a minimum of five weeks. Downward and upward arrowheads indicate the $65 \mathrm{kDa}$ and $55 \mathrm{kDa}$ proteins, respectively. 
associated proteins. However, the relevance of such alterations to their protective effect against thermal stress is not clear at the present stage. To answer these questions, it seems necessary to isolate the proteins concerned and to characterize them.

Possible changes in isozyme pattern (i.e. lactate dehydrogenase, isocitrate dehydrogenase, and phosphoglucomutase) following thermal acclimation were additionally analyzed by starch gel electrophoresis for muscle extracts from carp and goldfish (data not shown). However, changes were far less clear than those found by the conventional SDS-PAGE or the twodimensional electrophoretic analyses followed by protein staining. Two-dimensional electrophoresis in this study revealed that the 65 $\mathrm{kDa}$ protein was predominant in brain, muscle, and liver from the warm-acclimated fish. In addition, it was evident that the 28 and $97 \mathrm{kDa}$ proteins as well as the $65 \mathrm{kDa}$ proteins increasesed in the liver tissue extract from the warm-acclimated goldfish (see Fig. 2). It has been reported that the synthesis of an apolipoprotein with a molecular mass of $29 \mathrm{kDa}$ was enhanced in isolated hepatocytes from carp acclimated to summer temperatures. ${ }^{15}$ ) However, no proteins which may be induced simultaneously in several tissues at a moderately high acclimation temperature of $30^{\circ} \mathrm{C}$ have been reported, at least to our knowledge.

So far, no information seems to be available on the function of proteins specific to coldtemperature acclimation such as the $55 \mathrm{kDa}$ component found in this study. On the contrary, many studies concerning heat stress on cytosolic protein profiles have been carried out. Thermotolerance is acquired in animals which have been previously exposed to acutely elevated temperatures, in other words subjected to the wellknown "heat shock". ${ }^{16,17)}$ It is interesting that poikilothermic organisms inhabiting ecologically hot areas, such as desert areas, are easily induced to produce proteins resembling heat shock protein (hsp) $70 . .^{17-18)} \quad \mathrm{Hsp} 70$ is one of the most intensively investigated hsps and is known to be induced in organisms as diverse as humans and bacteria. Evolutionarily its amino acid sequence is highly conserved. ${ }^{14}$ ) The relevance of acclimation temperature to the induction of hsp70 has been reported in teleost cultured cells of catfish and medaka. ${ }^{20,212}$

The $65 \mathrm{kDa}$ protein produced in goldfish and carp after warm acclimation in this study was similar to hsp70 proteins in terms of isoelectric point, molecular weight, and wide distribution to various tissues. Reversible interaction of hsp70 proteins with ATP appears to be one of the fundamental properties of this protein family ${ }^{22}$ and the hsp70 protein from the mollusc Modiolus japonica has been reported to have such ATP binding properties. ${ }^{232}$ Therefore, the muscle extract from $30^{\circ} \mathrm{C}$-acclimated goldfish was applied to an ATP-agarose affinity column (Sigma), resulting in no protein eluted with $3 \mathrm{~mm}$ ATP (data not shown). Furthermore, the 65 $\mathrm{kDa}$ component showed no cross-reaction with monoclonal antibody against $72 \mathrm{kDa}$ hsp from HeLa cells (Amersham) in western blotting (data not shown). However, it is still unclear whether or not the $65 \mathrm{kDa}$ protein found in this study belongs to a family of hsp 70 proteins. Therefore, it seems necessary to determine the amino acid sequence of the present $65 \mathrm{kDa}$ protein, since hsp70 proteins are highly conserved in their sequences. ${ }^{14)}$ Such investigations are now in progress.

\section{Acknowledgements}

We thank Ms. M. N. Wilder, The University of Tokyo, for reading the manuscript. This study was partly funded by a Grand-in-Aid for Scientific Research from the Ministry of Education, Science, and Culture of Japan.

\section{References}

1) J. R. Hazel and C. L. Prosser: Molecular mechanisms of temperature compensation in poikilotherms. Physiol. Rev., 54, 620-677 (1974).

2) I. A. Johnston, W. Davison, and G. Goldspink: Adaptation in $\mathrm{Mg}^{2+}$ activated myofibrillar ATPase activity induced by temperature acclimation. FEBS Lett., 50, 293-295 (1975).

3) S. P. Heap and G. Goldspink: Consequences of thermal change on the myofibrillar ATPase of five fresh water teleosts. J. Fish Biol., 26, 733-738 (1985).

4) G.C. Hwang, S. Watabe, and K. Hashimoto: Changes in carp myosin ATPase induced by temperaturo accilmation. J. Comp. Physiol. B, 160, 233-239 (1990).

5) G. C. Hwang, Y, Ochiai, S. Watabe, and K. Hashimoto: Changes of carp myosin subfragment-1 induced by temperature acclimation, J. Comp. Physiol. B, 161, 141-146 (1991).

6) S. Watabe, G.-C. Hwang, M. Nakaya, F. Guo, and Y. Okamoto: Fast skeletal myosin isoforms in thermally acclimated carp. J. Biochem., 111, 113-122 (1992).

7) G. Gerlach, L. Turay, K. T. A. Malik, J. Lida, A. Seutt, and G. Goldspink: Mechanisms of temperature acclimation in the carp: A molecular approach. Am. J. Physiol, 259, R237- R244 (1990).

8) S. Watabe, G.-C. Hwang, H. Ushio, and K. Hashimoto: Biochemical responses to thermal acclimation in muscle proteins of carp, in "Current Topics in Marine Biotechnology" 
(ed, by S. Miyachi, I. Karube, and $\mathbf{Y}$, Ishida), The Japan Society for Marine Biotechnology, Tokyo, 1989, pp. 323-326

9) U. K. Laemmii: Cleavage of structural proteins during assembly of the head of bacteriophage T4. Nature, 227, 680-685 (1970),

10) P. H. O'Farrell: High resolution two-dimensional electrophoresis of proteins, J. Biol, Chem., 250, 4007-4021 (1975).

11) B. R. Oakley, D. R. Kirsch, and M. L. Morrís: A simplified ultrasensitive silver stain for detecting proteins in polyacrylamide gels. Anal. Biochem., 105, 361-363 (1980).

12) T. Nakagawa, $S$. Watabe, and $K$, Hashimoto: Identification of three major components in fish sarcoplasmic proteins. Nippon Suisan Gakkaishi, 54, 999-1004 (1988).

13) G. Hamoir: Earlier and recent work on parvalbumins, Symp. Biol. Hungarica, 17, 17-33 (1974)

14) S. Lindquist: The heat shock response. Ann. Rev. Biochem., 55, 1156-1191 (1986)

15) J. Inostroza, M. I. Vera, O. Goicoechea, R. Amthauer, and M. Krauskopf: Apolipoprotein A-1 synthesis during the acelimatization of the carp (Cyprinus carpio). J. Exp. Zool., 256, 8-15 (1990).

16) Y. Shimada: Induction of thermotolerance in fish embryo Oryzta latipes. Comp. Biochem. Physiol., 80 A, 177-181 (1985).

17) T. C. G. Bosch, S. M. Krylow, H. R. Bode, and R. E. Steele: Thermotolerance and synthesis of heat shock proteins: These responses are present in Hydra atle nuate but absent in Hydra oligachis. Proc. Natl. Acad. Sci. USA, 55, 7297-7931 (1988)

18) J. C. Near, D. P. Easton, P, S. Rutledge, D. P. Dickinson, and J. R. Spotila: Heat shock protein 70 gene expression in intact salamanders (Eurycea bislineafe) in response to caljbrated heat shocks and to high temperatures encountered in the field. J,Exp. Zool., 256, 303-314 (1990).

19) K. A. Ulmasov, S. Shammakov, K. Karaev, and M. B. Evgenev; Heat shock proteins and thermoresistance in lizards. Proc. Natl. Acad. Sci. USA, 89, 1666-1670 (1992).

20) M. Koban, G. Graham, and C. L. Prosser: Induction of heat-shock protein synthesis in teleost hepatocytes: Effects of acclimation temperature. Physiol. Zool., 60, 290-296 (1987).

21) S. Oda, O. Mitani, K. Naruse, and A. Shima: Synthesis of heat shock protein in the isolated fin of the medaka, Oryzias latipes, acclimated to yatious temperatures. Comp. Biochem. Physiol, 98 B, 587-591 (1991).

22) H. R. B. Pelham: Speculations on the functions of the major beat shock and glucose regulated proteins. Cell, 46, 959-961 (1986),

23) B. A. Margulis, Y. Antropiva, and A. D. Kharazova: $70 \mathrm{kDa}$ heat shock proteins from mollusc and human cells have common structural and functional domains. Comp. Biochem. Physiol., 94 B, 621-623 (1989). 